\title{
Do senso comum jurídico às funções latentes do trabalho prisional brasileiro*
}

\section{From the legal common sense to the latent functions of brazilian prison work}

Bertrand Wanderer ${ }^{1}$

* Recebido em: fevereiro de 2011.

Aprovado em: abril de 2012.

1 Graduado em Direito pelo Centro Universitário de Brasília. Especialista em Direito Penal pelo Instituto Processus de Cultura e Aperfeiçoamento Jurídico do Distrito Federal. Está concluindo curso de pós-graduação lato sensu em Ordem Jurídica e Ministério Público na Fundação Escola Superior do Ministério Público do Distrito Federal e Territórios. Atualmente é mestrando no curso de pós-graduação em Direito da Universidade de Brasília - UnB, área de concentração Direito, Estado e Constituição. É servidor público federal, exercendo o cargo de especialista em regulação de serviços públicos de telecomunicações (área jurídica) na Agência Nacional de Telecomunicações - ANATEL, lotado na Gerência de Defesa do Cumprimento de Obrigações Legais, Regulamentares e Contratuais.

\section{Resumo}

Este artigo faz de forma sucinta uma análise acerca do trabalho prisional, tendo por base as contribuições provenientes dos estudos desenvolvidos pela Criminologia Crítica, buscando relacionar o que propõe a norma jurídica brasileira acerca desse tema e, consequentemente, os efeitos decorrentes de sua aplicação no âmbito do sistema prisional brasileiro. A discussão terá início a partir do estudo historiográfico sobre a prisão, a relação entre trabalho e cárcere, utilizando-se, para tanto, das principais literaturas que versam sobre o respectivo tema. A partir da análise do surgimento da prisão e do seu natural desenvolvimento ao longo do tempo, buscar-se-á abordar os aspectos políticos, sociais e econômicos que influenciaram as suas transformações e que permitem a compreensão do atual modelo penal adotado. Por fim, tendo por base toda a argumentação teórica desenvolvida, pretende-se tecer algumas considerações sobre o assunto proposto. Em outras palavras, com base nas reflexões levantadas ao longo do texto, almeja-se, sem maiores pretensões, esclarecer e desmistificar as opiniões formuladas pelo senso comum e que, consequentemente, são absorvidas como verdades.

Palavras-chave: Trabalho prisional. Ressocialização. Discurso oficial. Ideologia da Defesa Social. Labeling Approach. Criminologia Crítica.

\begin{abstract}
This article is a succinct way of an analysis about the prison work, based on contributions from the studies developed by the Critical Criminology, trying to relate what is proposed by the rule of law in Brazil on this topic and therefore the effects of its application in within the Brazilian prison system. The discussion will start from the historiographical study on the arrest, the relationship between work and prison, using, for both, the major literatures that deal with the respective theme. From the analysis of the rise of the prison and its natural development over time, it will seek to address the political, social and economic aspects that influenced their transformations and enable the understanding of the current penal model adopted. Finally, based on all theoretical argument developed, it will be done a few remarks on the proposed issue. In other words, based on the ideas raised throughout the text, crave, without greater pretensions, clarify and demystify the views expressed by common sense and, consequently, absorbed as truth.
\end{abstract}

Keywords: Prison work. Resocialization. Official speach. Ideology of Social Defense. Labeling Approach. Critical Criminology. 


\section{Introdução}

Atualmente, muito se tem debatido acerca do sistema carcerário no que tange à má utilização do tempo dos encarcerados, uma vez que a maioria deles não exerce nenhum ofício dentro da prisão. Assim, há uma difusão da ideia de que o preso, durante o seu período de encarceramento, não exerce nenhuma atividade por simples falta de vontade, sendo dessa maneira caracterizado como um ser ocioso e que essa ociosidade, consequentemente, levao a praticar atos criminosos dentro dos presídios.

O trabalho prisional, segundo o discurso legal brasileiro, é um instrumento de reintegração social do condenado. Entretanto, o objetivo ora proposto visa analisar, brevemente, a razão pela qual a norma apresenta essa intenção moralizadora, mas, na prática, tende a não corroborá-la. A falsa consciência em torno dessa funcionalidade do sistema penal ${ }^{2}$ legitima processos de aplicação da lei de forma desigual e repressiva, o que contraria totalmente os discursos penais que se apresentam como justos, igualitários e comprometidos com a dignidade da pessoa humana.

Nesse sentido, a discussão sobre o tema em comento está baseada nas contribuições teóricas da Criminologia Crítica que, ao analisar as formas de funcionamento do sistema penal, identificou uma contradição entre o que é dito pela norma e o que é aplicado por aquele sistema. ${ }^{3}$ Quanto ao trabalho prisional, da mesma forma, ao contrário do que é expresso pela Lei de Execução Penal, ele não busca preparar o detento para o mercado de trabalho e, sim, perpetuar a segregação "natural" que o encarcerado sofre ao recuperar a liberdade.

A relação entre trabalho e prisão é regida pela ideia de que o trabalho, pelo menos no senso comum

\footnotetext{
2 “[...] o sistema penal não se reduz ao complexo estático das normas penais, mas é concebido como um processo articulado e dinâmico de criminalização ao qual concorrem todas as agências do controle social formal, desde o Legislador (criminalização primária), passando pela Polícia e a Justiça (criminalização secundária) até o sistema penitenciário e os mecanismos do controle social informal". ANDRADE, Vera Regina Pereira de. Do paradigma etiológico ao paradigma da reação social: mudança e permanência de paradigmas criminológicos na ciência e no senso comum. Revista Seqüência, Santa Catarina, v. 16, n. 30, 1995.

3 Essa contradição é chamada de crise de legitimidade pela Criminologia Crítica. Nesse sentido, ver: ZAFFARONI, Eugenio. Em busca das penas perdidas. Rio de Janeiro: Revan, 1991.
}

jurídico, deve ressocializar o sujeito. O labor, assim, é considerado como uma forma de propiciar ao detento uma vida melhor do que aquela que ele possuía antes de ingressar no cárcere, pois tomará conhecimento de novos valores sociais, aprenderá uma profissão ou, caso já a conheça, terá a oportunidade de aprimorá-la. Portanto, o uso do trabalho no ambiente carcerário, segundo esse pensamento, tem por objetivo atender a finalidade de reabilitar o transgressor, permitindo que a reinserção social seja alcançada.

Entretanto, o efeito estigmatizante que a prisão impõe ao preso lhe traz uma série de consequências, como, por exemplo, a não inserção no mercado de trabalho, seja pelo preconceito à sua qualidade de ex-detento, quanto pelos hábitos de preso que ele adquire. Trata-se de uma clara contradição entre o que pretende a norma e o que a prática social demonstra. Ao se analisarem os tipos de ofício oferecidos à massa carcerária, isto é, artesanato, panificação, funilaria, por exemplo, percebe-se que o detento está sendo preparado para, em breve, retornar ao seu verdadeiro ambiente: a prisão. Trata-se de trabalhos mecânicos, de pouca responsabilidade e de baixa complexidade intelectual, que não exigem mais que um simples treinamento para serem realizados. Em outros termos, uma das consequências se deve à falta de qualificação profissional do detento, uma vez que, na prisão, o condenado não aprende nenhum ofício que seja relevante.

\section{A criminologia crítica e o estudo historio- grárfico da prisão}

O Paradigma da Reação Social, também conhecido como teoria do Labeling Approach, surgiu nos Estados Unidos da América, em meados da década de 60 do século XX, como uma forma de se contrapor ao Paradigma Etiológico. ${ }^{4}$ Para esse movimento teórico, o crime é o resultado da própria interação social, ou seja, só há crime se houver uma prévia reação da sociedade, considerando aquela conduta praticada como lesiva ou desviante. Dessa

4 O Paradigma Etiológico surgiu em meados do século XIX com a Escola Positiva Italiana (é nesse momento, também, que a Criminologia surge como uma ciência). Esse movimento teórico tinha como objeto de estudo as causas do crime. Partia-se da ideia de crime já determinado e com isso procurava-se a causa que levou a pessoa a delinquir. $\mathrm{O}$ objeto de estudo das causas do crime, portanto, tinha o criminoso como aspecto central. 
maneira, diversamente do que ocorria anteriormente, o objeto de estudo da Criminologia deixa de ser o crime e o criminoso e passa a ser o processo de criminalização. Assim, a Criminologia desenvolvida a partir do Paradigma da Reação Social questiona os motivos que levam uma conduta a ser considerada como ilícita, quem é definido como criminoso, qual a razão de somente alguns serem definidos e quem estabelece tais definições.

Com base no estudo do processo de criminalização, o Labeling Approach identificou dois momentos distintos, que são: a criminalização primária e a secundária. O primeiro ocorre quando se definem quais serão as condutas consideradas ilícitas. Já o segundo ocorre quando se seleciona e aplica a um indivíduo a condição de criminoso. Por sua vez, dessas ações decorrem duas outras situações: o desvio primário e o secundário, respectivamente. O desvio primário é a primeira vez que o indivíduo transgride a regra pré-estabelecida. Já o desvio secundário é o efeito da aplicação da etiqueta desviante, criminoso, sobre o indivíduo, o que o leva a mudar o seu comportamento, assumindo o papel que lhe foi imposto.

Para essa perspectiva teórica, duas são as características marcantes do sistema penal, isto é, a seletividade e a estigmatização. ${ }^{5}$ É possível perceber que diante da criminalização de determinadas condutas, a consequência será, obrigatoriamente, a criminalização de determinadas pessoas. Isso se deve ao fato de que não é possível, dentro da própria estrutura do sistema penal, perseguir todas as condutas consideradas ilícitas e, muito menos todas as pessoas que as praticam. Logo, somente aquelas ações mais visíveis e repudiadas são perseguidas e, por sua vez, somente algumas e certas pessoas são alcançadas. Portanto, a seletividade é uma característica estrutural e não conjuntural do sistema penal.

Em decorrência da prática seletiva, aparece a estigmatização, que é o resultado da aplicação com êxito da etiqueta de criminoso, isto é, do processo de criminalização secundário. Essa marca, uma vez recebida pelo indivíduo, provoca uma mudança em sua identidade social e se torna, muitas vezes, irreversível. Dessa forma, as chances desse mesmo indivíduo voltar a delinquir aumentam, uma vez que ele já está marcado pela sociedade e pelo

BARATTA, Alessandro. Criminologia crítica e crítica do direito penal: introdução à sociologia jurídico-penal. Rio de Janeiro: Revan, 2002. próprio sistema penal. Alessandro Baratta afirma que as regras e os objetivos do sistema social e as relações de poder e propriedade interferem na distribuição do status social positivo e negativo. Então, os bens, os direitos, o poder, a riqueza, a beleza e o conforto são bens positivos, são etiquetas positivas. Logo, a mesma regra social, as mesmas relações econômicas e de poder que estruturam a sociedade de maneira desigual, são as mesmas responsáveis pela distribuição desigual do status de criminoso. ${ }^{6}$

Assim, verifica-se que a função reeducativa e ressocializadora da pena não pode ser alcançada, haja vista a incompatibilidade entre o que prevê a norma e a sua aplicabilidade. Percebe-se que há uma falsa consciência em torno dessa funcionalidade do sistema penal, a qual legitima processos de aplicação da lei de forma desigual e repressiva, o que contraria, totalmente, os discursos penais que se apresentam como justos, igualitários e comprometidos com a dignidade da pessoa humana.

Diante disso, surge a Criminologia Crítica, que, utilizando-se dos estudos realizados pelo Labeling Approach, promoverá uma identificação mais detalhada e profunda da lógica de atuação do sistema penal. Uma de suas contribuições foi a de revelar a crise de legitimidade desse sistema, que decorre da contradição entre as funções declaradas e as latentes. É importante ressaltar que essa crise não é de existência, ou seja, não cabe melhorar a LEP; não basta, apenas, melhorar os presídios, trata-se de uma crise de identidade. Logo, surge o seguinte questionamento: o sistema penal não cumpre as funções que declara porque elas são inalcançáveis ou porque essas não são as funções que ele pretende alcançar?

Cumpre salientar, ainda, que esse movimento teórico discute os deveres da pena, a quem ela se destina, quem a produz, quais os fins que ela cumpre alcançar, quais as suas funções. Com base nisso, verifica-se que o sistema penal é utilizado como uma forma de reprodução das desigualdades sociais, isto é, de se manter uma determinada forma de ordem estrutural, tornando-se, portanto, injusta, desigual, arbitrária e violenta.

Além disso, os estudos da Criminologia Crítica estão embasados também na crítica historiográfica à prisão,

6 BARATTA, Alessandro. Criminologia crítica e crítica do direito penal: introdução à sociologia jurídico-penal. Rio de Janeiro: Revan, 2002. 
tendo em vista que a incompatibilidade entre a norma e a sua aplicação não é recente, mas remonta ao período do surgimento da instituição carcerária.

\subsection{0 surgimento da prisão}

A prisão não é um instituto moderno e a sua origem remonta ao período do feudalismo. Entretanto, nessa época, o cárcere não possuía um caráter de punição, como se observa nas palavras de Dário Melossi:

Num sistema de produção pré-capitalista, o cárcere como pena não existe. Essa afirmação é historicamente verificável, advertindo-se que a realidade feudal não ignora propriamente o cárcere como instituição, mas sim a pena do internamento como privação de liberdade. ${ }^{7}$

Observa-se que, já no Estado Absolutista, a prisão existia. Porém, não se tinha a privação de liberdade como castigo. Considerava-se o cárcere como um local onde os condenados ficavam aguardando o cumprimento da pena capital. Nessa época, as penas que se voltavam contra o corpo do condenado, não necessariamente o suplício, eram as formas mais usuais de punição àqueles que infringiam as normas. Tratava-se de um espetáculo público, pois a pena corpórea servia a duas finalidades: reafirmar o poder do príncipe, o qual foi ofendido na sua honra pela prática delituosa; ${ }^{8}$ e deixar um exemplo ao restante do povo do que acontece com aqueles que desrespeitam as regras. ${ }^{9}$ Portanto, a punição do delito refletia a vingança que o rei promovia contra aquele que descumpria as suas determinações. Isso porque: "A infração não é um dano cometido por um indivíduo contra o outro; é uma ofensa ou lesão de um indivíduo à ordem, ao Estado, à lei, à sociedade, à soberania, ao soberano". ${ }^{10}$

Nesse período, vigorava o suplício do corpo. Tratava-se de uma forma de exercício de poder baseado no medo, em que se buscava imprimir no próprio corpo do criminoso a marca do seu castigo. Michel Foucault deixa claro que esses suplícios não eram frequentes, buscava-se manter uma proporção entre o delito e a sua punição. Po-

7 MELOSSI, Dario; PAVARINI, Massimo. Cárcere e fábrica: as origens do sistema penitenciário (séculos XVI - XIX). Rio de Janeiro: Revan, 2006. p. 21.

8 FOUCAULT, Michel. Vigiar e punir: nascimento da prisão. Petrópolis: Vozes, 1987, p. 42.

9 Ibidem, p. 31-32. rém, os mais graves como o homicídio, eram punidos com a morte.

Além disso, o processo e o julgamento eram realizados sob o manto do sigilo, o que proporcionava ao “[...] soberano e aos seus juízes um direito absoluto e um poder exclusivo". ${ }^{11}$ Dessa maneira, o processo medieval era marcado por uma sucessão de interrogatórios dirigidos para a confissão, sob juramento ou tortura, em completa ignorância à acusação e às provas.

Diante dessa insegurança jurídico-política, a qual acarretava uma incerteza das penas, a sociedade, pouco a pouco, começou a vislumbrar que ela poderia ser a próxima vítima desse soberano arbitrário. Assim, começa a haver uma mudança na visão de quem será considerado como criminoso, pois se questionam a proporcionalidade entre o crime cometido e a punição aplicada. Logo,

A punição pouco a pouco deixou de ser uma cena. E tudo que pudesse implicar de espetáculo desde então terá um cunho negativo; e como as funções da cerimônia penal deixavam pouco a pouco de ser compreendidas, ficou a suspeita de que tal rito que dava um 'fecho' ao crime mantinha com ele finalidades espúrias: igualando-o, ou mesmo ultrapassando-o em selvageria, acostumando os espectadores a uma ferocidade de que todos queriam vê-los afastados, mostrando-lhes a freqüência dos crimes, fazendo o carrasco se parecer com criminoso, os juízes aos assassinos, invertendo no último momento os papéis, fazendo do supliciado um objeto de piedade e de admiração. ${ }^{12}$

Assim, diante desse sentimento de insegurança, aliado às mudanças nas esferas social, política e econômica, o poder de punir mudou o seu objeto de atuação. Os reformadores ${ }^{13}$ do século XVIII iniciaram os apelos para promover a suspensão dos suplícios, alegando que

${ }^{11}$ FOUCAULT, Michel. A verdade e as formas jurídicas. Rio de Janeiro: Nau, 2001. p. 32-33.

12 Idem. Vigiar e punir: nascimento da prisão. Petrópolis: Vozes, 1987. p. 12-13.

${ }^{13}$ Autores como Cesare Beccaria, Jeremy Bentham, Gaetano Filangieri, Giandomenico Romagnosi, Pablo Anselmo Von Feuerbach, Giovanni Carmignani, Pellegrino Rossi, Francesco Carrara, entre outros. 
a justiça penal deveria punir ao invés de se vingar. ${ }^{14}$ Eles estavam pensando em um tipo de resposta aos problemas existentes na época e estavam tentando elaborar um sistema em que as penas fossem análogas aos crimes, retomando uma ideia de proporcionalidade. ${ }^{15}$ Os reformadores queriam uma justiça mais rápida e, por conta disso, trabalhavam a ideia de leis mais claras e que todos pudessem conhecer. Em outras palavras, uma linguagem simples para que todos soubessem qual é a regra e a forma de punição para a sua transgressão. $\mathrm{O}$ fundamento jurídico disso tudo foi o contrato social. ${ }^{16}$

\footnotetext{
${ }^{14}$ Nasce, nesse contexto, a chamada Escola Clássica, a qual promoverá uma crítica ao Antigo Regime. Os pensadores dessa Escola vão afirmar que o antigo regime é um sistema punitivo excessivo, não regulamentado, lacunoso, que não respeita a humanidade. No âmbito do Direito Penal, trabalhou em prol da segurança jurídica, da suavização das penas, buscando estabelecer um novo sistema punitivo a partir de dois parâmetros: humanidade e proporcionalidade. Para os, clássicos, o crime deixa de ser uma ofensa ao poder soberano e passa a ser um ente jurídico, fruto da razão, dada a fonte racionalista da norma jurídica. A responsabilidade penal, por sua vez, vem da responsabilidade moral derivada do livre-arbítrio que as pessoas têm de infringir uma norma, sendo essa uma palavra fundamental no pensamento clássico. A pena, na concepção da Escola Clássica, deve ser proporcional. É um justo e proporcionado castigo que a sociedade impõe a quem o merece, ou seja, ao delinquente. A pena deve ser útil, precisa, proporcional e justa. $\mathrm{O}$ aspecto principal dessa Escola era o crime. Ela estava preocupada em estabelecer balizas para um sistema jurídico seguro, equilibrado, mais normatizado.

${ }^{15}$ A noção de proporcionalidade não foi inaugurada nessa época. De uma forma ou de outra, ela já estava presente na Lei de Talião, no sentido de que os limites do castigo não deveriam ultrapassar a extensão exata dos danos causados pelo crime. Não se admitia mais o descompasso entre o delito e a sua respectiva pena. Nesse sentido, "[...] a pena consiste em fazer com que o dano não possa ser novamente cometido; em fazer com que o indivíduo em questão ou os demais não possam mais ter vontade de causar à sociedade o dano anteriormente causado; em fazê-los repugnar para sempre o crime que cometeram. E para obter esse resultado, a pena ideal, que se ajusta na medida exata, é a pena de talião" FOUCAULT, Michel. A verdade e as formas jurídicas. Rio de Janeiro: Nau, 2001. p. 82-83.

16 Trata-se de uma concepção filosófica de autoria de Jean-Jacques Rousseau, o qual é considerado com um dos mais importantes pensadores franceses do século XVIII no campo da política, da moral e da educação, influenciando os ideais do Iluminismo e da Revolução Francesa. Segundo Rousseau, é possível formular uma sociedade em que os homens sejam livres e iguais. Para tanto, necessário se faz celebrar um Contrato Social entre todos os membros que compõem a sociedade, para que, assim, preserve-se a liberdade natural do homem e ao mesmo tempo se garanta a segurança e o bem-estar que a vida em sociedade pode proporcionar.
}

Contudo, essa mudança de pensamento não foi alimentada apenas por um sentimento de sensibilidade e humanitarismo. Há, nesse período, o desenvolvimento da produção, o aumento das riquezas, uma valorização jurídica e moral das relações de propriedade e, consequentemente, há também uma modificação na criminalidade.

Desde o fim do século XVII, com efeito, nota-se uma diminuição considerável dos crimes de sangue e, de um modo geral, das agressões físicas; os delitos contra a propriedade parecem prevalecer sobre os crimes violentos; o roubo e a vigarice sobre o assassinato, os ferimentos e golpes; a delinqüência difusa, ocasional, mas freqüente das classes mais pobres é substituída por uma delinqüência limitada e 'hábil.'. ${ }^{17}$

Dessa forma, para atender a essa realidade, uma nova forma de punir deveria ser colocada em ação. Muda-se o foco da pena, saindo do corpo e partindo-se para o bem maior do homem, ou seja, sua liberdade, sua alma. Essa mudança não se trata de uma redução da brutalidade da pena, mas da sua transformação para a nova época que se vivia.

Apesar disso, nesse período, existia uma tendência de se generalizar um tipo de controle muito comum nos manicômios, nos conventos e nos quartéis, que é o disciplinar. Isso se deve ao fato de a disciplina ser encarada como um instrumento de controle e domínio das massas, pois ao mesmo tempo busca potencializar suas forças em termo de utilidade econômica e minimizar essas mesmas forças em termos de obediência política.

Segundo Michel Foucault, a disciplina se utiliza de elementos e métodos específicos. Como elementos, temos: I) a arte das distribuições - “[...] lugares determinados se definem para satisfazer não só à necessidade de vigiar, de romper as comunicações perigosas, mas também de criar um espaço útil"18; II) o controle da atividade - "[...] um corpo disciplinado é a base de um gesto eficiente"19; III) a organização das gêneses - divisão do conhecimento a ser adquirido, sua organização sequencial, termo para alcançá-lo, estabelecimento de séries de aprendizado, utilização do exercício para a sua fixação; IV) composição das forças - articulação funcional das forças corporais em aparelhos eficientes.

\footnotetext{
${ }^{17}$ FOUCAULT, Michel. A verdade e as formas jurídicas. Rio de Janeiro: Nau, 2001. p. 64-65.

${ }^{18}$ Idem. Vigiar e punir: nascimento da prisão. Petrópolis: Vozes, 1987. p. 123.

${ }^{19}$ Ibidem, p. 130.
} 
Apesar do saber adquirido por meio dessas técnicas, Michel Foucault afirma que o sucesso do poder disciplinar se deve à utilização dos seguintes métodos: a vigilância hierárquica, a sanção normalizadora e o exame. A vigilância hierárquica consiste no controle sobre o corpo alheio, realizado por relações de controle vertical, exercidas por olhares constantes de vigias, que fiscalizam permanentemente os seus subordinados. Assim, o poder disciplinar se torna onipresente, pois está em toda a parte, acompanhando e fiscalizando cada atividade. A sanção normalizadora é exercida por meio de um sistema de recompensa (gratificação) e de punição (castigo), que tem por finalidade corrigir e reduzir os desvios. Para tanto, pune-se qualquer tipo de transgressão, seja um pequeno atraso ou uma desobediência. Não há espaço para a tolerância. Por fim,

[...] o exame combina as técnicas da hierarquia que vigia e as da sanção que normaliza. É um controle normalizante, uma vigilância que permite qualificar, classificar e punir. Estabelece sobre os indivíduos uma visibilidade através da qual eles são diferenciados e sancionados. É por isso que, em todos os dispositivos de disciplina, o exame é altamente ritualizado. ${ }^{20}$

Em suma, por meio desses métodos, um saber é extraído das relações de poder e, por sua vez, o saber legitima e reproduz o poder.

Diante de todos esses elementos, Michel Foucault utiliza a figura arquitetural do Panóptico criada por Jeremy Bentham, porque ela reúne em um só instrumento todas as técnicas desenvolvidas pela disciplina. Trata-se de uma torre central e um anel periférico que a circunda. A torre concentra a função de vigiar os residentes do anel. Nesse se encontram escolares, os trabalhadores, os criminosos, todas as pessoas que devem ficar sujeitas a fiscalização. Esses "moradores" não têm visão um dos outros, encontram-se, cada um, enclausurados em suas celas, tendo como sua única visão a torre central. Essa realiza a vigilância de todo o complexo, mas em contrapartida, devido a sua própria estrutura não permite que aqueles que se encontram fora dela, visualizem o que se passa em seu interior. Dessa forma, o sujeito que fica no anel não sabe se está sendo realmente vigiado e isso acaba "[...] induzindo no detento um estado consciente e permanente de visibilidade que assegura o funcionamento automático do

${ }^{20}$ FOUCAULT, Michel. Vigiar e punir: nascimento da prisão. Petrópolis: Vozes, 1987. p. 154. poder". ${ }^{21}$ Cria-se, portanto, "uma espécie de laboratório de poder"22, que acaba permitindo uma ordenação mais efetiva das multiplicidades humanas. Desse modo, está inaugurada a nova anatomia política.

O modelo Panóptico acabava por resumir a ideia da disciplina, em que corpos fracos, preguiçosos, por meio de regras rigorosas e bem determinadas se tornavam úteis e eficientes. Essa ideia, aliada às finalidades do capitalismo nascente, fez com que as prisões canalizassem o uso da disciplina para o trabalho do encarcerado. Portanto, é da metade para o fim do século XVIII que a prisão passa a ser considerada como uma forma de punição. Em outras palavras, a prisão passou a consistir “[...] do uso da privação da liberdade e da supressão do tempo do condenado como forma de castigo, em função de uma conduta do mesmo considerada criminosa".23

Por volta do fim do século XVIII e início do século XIX, surge a ideia da ressocialização pela pena com a chamada Escola Positiva Italiana. Nessa fase, buscava-se com as pesquisas criminais determinar as causas do crime, identificando a figura do criminoso e tentando prever as consequências dos delitos. Para os autores dessa época, o criminoso era um ser anômalo à sociedade, doente e, portanto, era necessário curá-lo. Dessa maneira, observa-se que:

\section{[...] na sua origem, a instituição prisional pres- supunha dois objetivos definidos: de um lado, alijar e, portanto, punir os sujeitos que violaram os preceitos éticos comuns que harmonizam o corpo social, e, de outro, corrigir, disciplinar e reabilitar os mesmos, a fim de lhes possibilitar a reintegração a este mesmo corpo. ${ }^{24}$}

Assim, a restrição da liberdade, por meio da prisão, torna-se a forma de castigo por excelência. Porém, além de punir o responsável pelo delito, o cárcere passa a ter um novo objetivo, ou seja, a reinserção social do criminoso. Nesse momento, o trabalho prisional ganha um papel de relevo no tratamento do delinquente. Entretanto, é preciso compreender como o trabalho foi introduzido no ambiente carcerário e, por fim, tornou-se um ele-

${ }^{21}$ FOUCAULT, Michel. Vigiar e punir: nascimento da prisão. Petrópolis: Vozes, 1987. p. 166.

${ }^{22}$ Ibidem, p. 169.

${ }^{23}$ ZACKSESKI, Cristina. Relações de trabalho nos presídios. Revista do Ministério Público do Trabalho, Brasília, n. 23, p. 31, mar. 2002.

${ }^{24}$ FREIRE, Christiane Russomano. A violência do sistema penitenciário brasileiro contemporâneo. O caso RDD (Regime Disciplinar Diferenciado). São Paulo: IBCCRIM, 2005, p. 53. 
mento importante na justificação da existência da prisão, a partir da ideia da recuperação do detento.

\subsection{0 trabalho prisional e seus objetivos}

Com o declínio do sistema feudal de produção e o surgimento da manufatura, a qual exigia a obtenção de matérias-primas específicas, acrescido pelo esgotamento do solo e decréscimo das colheitas, isso fez com que as lavouras, pouco a pouco, fossem substituídas pela criação de animais. Essas modificações fizeram com que os camponeses perdessem sua utilidade no campo. Por outro lado,

[...] as cidades, que já representavam, com o desenvolvimento da atividade econômica e, em particular, do comércio, um pólo de atração notável, começaram a povoar-se com milhares de trabalhadores expropriados, convertidos em mendigos, vagabundos, às vezes bandidos, porém, em geral, numa multidão de desempregados. ${ }^{25}$

Apesar do grande número de desempregados nas cidades, as primeiras manufaturas não colaboravam para mudar essa situação. Devido ao trabalho realizado, elas exigiam de seus empregados uma certa familiaridade com os serviços, circunstância essa, que não podia ser acompanhada pelos camponeses, acostumados à atividade agrícola. Além disso, o ritmo monótono, mecânico e repetitivo do trabalho fabril desmotivava muitas pessoas, o que gerava uma série de reclamações dos empresários sobre a falta de disposição dos operários.

O capitalismo nascente encontrou nas ideias do Protestantismo e do Calvinismo as bases para o seu desenvolvimento. ${ }^{26} \mathrm{~A}$ reforma religiosa promovida por esses dois se-

${ }^{25}$ MELOSSI, Dario; PAVARINI, Massimo. Cárcere e fábrica: as origens do sistema penitenciário (séculos XVI - XIX). Rio de Janeiro: Revan, 2006. p. 34.

26 "As religiões protestantes e em particular o calvinismo forneceram sem dúvida, muito mais do que a religião católica, uma visão abrangente do mundo e da vida baseada na ética do trabalho, a religião do capital, que animará por si mes$\mathrm{ma}$ as primeiras instituições segregadoras. $\mathrm{Na}$ passagem da sociedade camponesa medieval para a sociedade burguesa industrial, o trabalhador não está mais sujeito a um vínculo direto e imediato com o senhor, vínculo esse jurídico e militarmente garantido e justificado, ao nível ideológico, por uma visão teocrática abrangente da vida. Ele deve ser conduzido, doravante, por uma força muito mais indireta, a da coação econômica. Porém, só quando o capitalismo alcançar seu completo desenvolvimento, com a garantia da sua hegemonia material e ideológica sobre toda a sociedade, é que a força da necessidade se tornará uma força realmente eficiente de regulação social." MELOSSI, Dario; PAVARINI, Massimo. Cárcere e fábrica: as origens do sistema penitenciário (séculos XVI - XIX). Rio de Janeiro: Revan, 2006, p. 50. guimentos permitiu que duas concepções ganhassem força nessa época, que são: o acúmulo de capital e exercício do trabalho como condição para uma vida digna. Dessa maneira, a visão que se tinha da mendicância foi modificada, passando a ser considerada "como pecado de indolência."27 Logo, diante dessa nova visão da realidade e para atender as exigências do mercado de manufatura, começou a ser propagado o sentimento de que "o dever com o trabalho é a essência da vida.".28

Obviamente, muitos trabalhadores não puderam ser persuadidos a aceitar essa nova teoria voluntariamente, nem tampouco a disciplina severa imposta pelo catecismos foi suficiente para resolver os problemas sociais. Foram necessárias medidas mais radicais, como as casas de correção, onde os mais resistentes eram forçados a forjar seu cotidiano de acordo com as necessidades da indústria. ${ }^{29}$

Assim, as casas de trabalho foram utilizadas para solucionar a escassez de mão de obra. Em um primeiro momento, o trabalho desenvolvido nesses locais era interessante, pois atendia aos anseios dos empregadores em dois sentidos: por um lado, reunia naquela instituição uma mão de obra barata que realizava o trabalho desejado a custos mínimos; por outro, intimidava o operário livre que não desejando ser recolhido àquela, aceita as condições impostas pelo trabalho.

Posteriormente, com o advento da Revolução Industrial, houve um aumento na oferta de trabalho o que contribuiu, consequentemente, para o fim do aspecto intimidatório das casas de trabalho. Isso se deve ao fato de que a incorporação da ideia do trabalho não foi desenvolvida apenas nesses locais. As instituições de ensino também tinham seu papel, ou seja, cabia a elas desenvolver nas crianças as habilidades necessárias para o trabalho fabril, formando, dessa maneira, o futuro contingente de operários. Essa circunstância, aliada ao desenvolvimento tecnológico das indústrias, fez com que as casas de trabalho perdessem seu atrativo. Em outras palavras, havia um número suficiente de trabalhadores livres capazes de atender as novas demandas que o mercado de trabalho exigia, isto é, qualificação técnica. Logo, desenvolver tais exigências nos ociosos, vagabundos, delinquentes, tornava-se extremamente oneroso.

\footnotetext{
${ }^{27}$ RUSCHE, Georg; KIRCHHEIMER, Otto. Punição e estrutura social. Rio de janeiro: Revan, 2004, p. 64.

${ }^{28}$ Ibidem, p. 68.

${ }^{29}$ Ibidem, p. 68-69.
} 
Nesse período, as casas de trabalho perdem a sua força, entretanto, as instituições carcerárias começam a ter um valor mais marcante na sociedade. $\mathrm{O}$ crescente progresso econômico auxiliou na transformação do regime político, ou seja, com o declínio do Absolutismo e o surgimento do Estado Liberal, a privação da liberdade assume, em concreto, o papel de instrumento de punição.

Somente a sociedade industrial (leia-se sociedade disciplinar moderna) foi capaz de impor à liberdade humana um referencial valorativo, à semelhança do preço estabelecido aos bens transformados em mercadorias. A partir do momento em que o tempo despendido na produção imprimiu a medida de valor às mercadorias, foi possível, em sentido inverso, conferir à restrição ou à perda da liberdade o significado de desvalor. Dito de outro modo, estar alijado de seu tempo significa estar destituído daquilo que lhe possibilita agregar valor econômico. É dentro desse referencial simbólico que encontramos lógica entre privação de liberdade e sanção penal. ${ }^{30}$

Assim, a prisão passa a ser encarada sobre um duplo aspecto, ou seja, jurídico e econômico. Ela visa cobrar a dívida criada pelo crime e para isso restringe a liberdade daquele que a promoveu. Contudo, por trás desse seu objetivo "justo", ela deve cumprir com a sua função primordial, qual seja, "deve ser um aparelho disciplinar exaustivo." ${ }^{31}$ A prisão colocará em prática tudo aquilo que foi desenvolvido pela disciplina. Promoverá, portanto, o isolamento (com a ruptura das relações horizontais), o trabalho (como mecanismo de submissão ao poder) e a modulação da pena como, valor de troca medido pelo tempo.

Nesse segundo momento, a utilização do trabalho nas prisões não servirá apenas para atender a necessidade de ocupar o tempo do encarcerado ${ }^{32}$, mas também para tornar vantajosa a sua atividade. Em outras palavras, justifica-se o trabalho prisional no sentido de que, como o

\footnotetext{
${ }^{30}$ FREIRE, Christiane Russomano. A violência do sistema penitenciário brasileiro contemporâneo. O caso RDD (Regime Disciplinar Diferenciado). São Paulo: IBCCRIM, 2005. p. 51.

${ }^{31}$ FOUCAULT, Michel. Vigiar e punir: nascimento da prisão. Petrópolis: Vozes, 1987. p. 198.

${ }^{32}$ Haja vista que se mantinha a ideia de que esse "[...] era considerado ao mesmo tempo a receita de uma vida meritória, piedosa, e a regra básica da ordem social". BAUMAN, Zygmunt. Globalização: as consequências humanas. Rio de Janeiro: J. Zahar, 1999. p. 117.
}

criminoso causou um dano à sociedade, nada mais justo que ele trabalhe e com isso repare o seu prejuízo. ${ }^{33}$

Porém, o objetivo do trabalho prisional, nesse período, não era preparar o indivíduo para o mercado de trabalho, mas visava instituir nele o gosto pelo trabalho. $\mathrm{O}$ importante não era aprender um ofício, mas trabalhar por trabalhar, formando, assim, um trabalhador ideal. ${ }^{34} \mathrm{Em}$ outras palavras, um servidor submisso que não questionasse as ordens, mas que as cumprisse com total dedicação.

Esse pensamento persistiu até o fim do Estado Liberal, mas com o advento do Estado Social, que apresentou um contínuo desenvolvimento tecnológico, científico e econômico, a justificativa para o uso da prisão passou por uma transformação. Nesse novo contexto, a restrição da liberdade deveria ser utilizada para reeducar o criminoso, pois esse passa a ser considerado como um ser doente, que necessita de cuidados. Dessa forma, na segunda metade do século XIX, o sistema de justiça penal passa a ser construído a partir de um modelo correcional de justiça, tendo em vista o fim de prevenção especial positiva. ${ }^{35}$ Em outras palavras, a pena deve almejar a reintegração social do encarcerado e o trabalho, nesse contexto, assume um importante papel para a realização desse intuito, isto é, ele deixa de ser apenas um meio de reparação do dano causado à sociedade para se tornar um remédio. ${ }^{36}$

${ }^{33}$ Trata-se de uma ideia trazida pelos reformadores da Escola Clássica, na qual a pena consiste “[...] em forçar as pessoas a uma atividade útil ao Estado ou à sociedade, de tal forma que o dano causado seja compensado". FOUCAULT, Michel. A verdade e as formas jurídicas. Rio de Janeiro: Nau, 2001. p. 82.

${ }^{34}$ FOUCAULT, Michel. Microfísica do poder. Sobre a prisão. Rio de Janeiro: Graal, 1992. p. 133.

${ }^{35}$ PAVARINI, Massimo. A "grotesca" penalogia contemporânea. Seminário realizado em 03 de dezembro de 2002, no Doutorado do Centro di Studi sul Rischio - Università di Lecce.

${ }^{36}$ Essa nova forma de ver a criminalidade e de combatê-la se deve à Escola Positiva Italiana que tinha como aspecto central do seu estudo o criminoso. Surge, aqui, a Criminologia como Ciência e, consequentemente, como fruto de suas pesquisas o Paradigma Etiológico. "Na base deste paradigma a Criminologia é definida como uma ciência causal explicativa da criminalidade: ou seja, que tendo por objeto a criminalidade concebida como um fenômeno natural, causalmente determinado, assume a tarefa de explicar as suas causas segundo o método científico ou experimental e o auxílio de estatísticas criminais oficiais e de prever remédios para combatê-la. Ela indaga, fundamentalmente, o que o homem (criminoso) faz e porque o faz". ANDRADE, Vera Regina Pereira de. Do paradigma etiológico ao paradigma da reação social: mudança e permanência de paradigmas criminológicos na ciência e no senso comum. Revista Sequência, v. 16, n. 30, 1995. Desta Escola, Lombroso, Ferri e Garófalo foram os principais expoentes. 


\subsection{A prisão como instrumento de disciplina}

Pode se dizer que o sistema punitivo do século XX foi o resultado das mudanças realizadas nos séculos XVIII e XIX. Uma concepção cunhada nesse período e que se mantém até os dias atuais é o de que o trabalho é um instrumento útil para promover a reabilitação e reinserção social do criminoso. Isso se deve ao surgimento de uma ideologia que Alessandro Baratta denominou de Ideologia da Defesa Social, atribuindo a sua gênese às contribuições feitas pelas Escolas Clássica e Positiva italiana. Trata-se de uma falsa consciência que legitima o sistema penal, atribuindo-lhe uma função diversa da que realmente exerce. ${ }^{37}$

Segundo esse mesmo autor, observa-se pela análise da história, que a prisão, desde o seu início, não realizava o que pretendia, ou seja, a reforma do infrator. Ao contrário, por não atingir os seus objetivos, permitia a reincidência e, de certa forma, organizava a delinquência. Por conta disso, sempre foi alvo de críticas e reformas ao longo do tempo. Dessa forma, afirma que a prisão não cumpre o seu papel legal, qual seja, reeducar e promover a reinserção social do preso. ${ }^{38}$

$\mathrm{Na}$ visão do autor italiano, o preso é submetido a um duplo processo de transformação a partir do momento em que ingressa no cárcere. Primeiramente, ele é submetido a um processo de "desculturação", ou seja, "distanciamento progressivo dos valores e dos modelos de comportamento próprios da sociedade externa." ${ }^{" 39} \mathrm{Em}$ um segundo momento, há a "aculturação" ou "prisionalização", isto é, "[...] trata-se da assunção das atitudes, dos modelos de comportamento, dos valores característicos da subcultura carcerária." ${ }^{30}$

Por meio desses dois processos, deixa-se de lado a reinserção do condenado. O que se busca, verdadeiramente, é a educação para ser criminoso e a educação para ser um bom preso. A primeira é alcançada por meio das relações interpessoais as quais o condenado é submetido no ambiente carcerário. O segundo é o resultado tanto do cumprimento das normas da Instituição (for-

\footnotetext{
${ }^{37}$ BARATTA, Alessandro. Criminologia crítica e crítica do direito penal: introdução à sociologia jurídico-penal. Rio de Janeiro: Revan, 2002.

${ }^{38}$ Ibidem.

${ }^{39}$ Ibidem, p. 184.

${ }^{40}$ Ibidem.
}

mais), quanto das regras instituídas pela equipe da prisão (informais). ${ }^{41}$ Dessa forma,

A execução penal converte-se numa atividade produtora e reprodutora de etiquetas com as quais se julgam as personalidades e se definem os comportamentos. A ressocialização não pode ser conseguida numa Instituição como a prisão. Os centros de execução penal, as penitenciárias, tendem a converter-se num microcosmos no qual se reproduzem e se agravam as graves contradições que existem no sistema social exterior. É impossível conseguir a adaptação à vida que existe fora de uma instituição total como a prisão. A única adaptação possível é a adaptação aos regulamentos disciplinários que são impostos rigidamente. A situação agrava-se ainda mais quando o interno é posto em liberdade, já que sai marcado por um prognóstico desfavorável de conduta (classificado como perigoso ou não confiável) que inegavelmente o marginalizará para sempre. A pena privativa de liberdade não ressocializa, ao contrário, estigmatiza o recluso, impedindo sua plena reincorporação ao meio social. A prisão não cumpre uma função ressocializadora. Serve como instrumento para a manutenção social dominante. ${ }^{42}$

Nesse sentido, Alessandro Baratta utilizou-se das obras de Georg Rusche e Otto Kirchheimer e de Michel Foucault, as quais já haviam demonstrado que o cárcere, dentro do sistema capitalista de produção, cumpre com as funções às quais foi criado. Portanto,

[...] é impossível enfrentar o problema da marginalização criminal sem incidir na estrutura da sociedade capitalista, que tem necessidade de desempregados, que tem necessidade, por motivos ideológicos e econômicos, de uma marginalização criminal. ${ }^{43}$

Assim, o sistema penitenciário, ao invés de reduzir a criminalidade, promove a sua continuidade. Trata-se de um instrumento de dominação que cumpre atender aos interesses de uma determinada classe em detrimento das demais. Portanto, a prisão dentro desse contexto não fracassou, pelo contrário, segundo Michel Foucault, vem atendendo ao seu real objetivo, qual seja, realizar uma gestão diferenciada da criminalidade. ${ }^{44}$

${ }^{41}$ BARATTA, Alessandro. Criminologia crítica e crítica do direito penal: introdução à sociologia jurídico-penal. Rio de Janeiro: Revan, 2002. p. 185.

42 BITENCOURT, Cézar Roberto. O objetivo ressocializador na visão da criminologia crítica. Revista dos Tribunais, São Paulo, ano 79, v. 662, p. 250, dez. 1990.

${ }^{43}$ Ibidem, p. 190.

${ }^{44}$ FOUCAULT, Michel. Vigiar e punir: nascimento da prisão. Petrópolis: Vozes, 1987. 


\subsection{A prisão como instrumento de exclusão}

Pode-se constatar que o sistema penal está imbricado em uma contradição: de um lado, há o discurso oficial que, buscando proteger valores essenciais à vida, determina a imputação de sanções contra aqueles que não respeitam as suas deliberações (caráter retributivo); e, ainda, busca meios de reintegrar o indivíduo delituoso à sociedade (ressocialização). Por outro lado, a realidade que se vê, como consequência da aplicação dessas normas, é diversa. Em outras palavras, a função real que o Direito Penal promoveu, durante a primeira metade do século XX, foi de "produção e reprodução de desigualdades sociais" ${ }^{45}$

Tendo em vista essa realidade e aliado às mudanças econômicas promovidas pelos processos de globalização, a partir da segunda metade do mesmo século, começa a haver uma rediscussão sobre os objetivos do Estado, graças às ideias neoliberais que foram surgindo. Uma dessas ideias que ganhou força e que influenciou na modificação da finalidade real da pena foi a que pregava a transição do Estado social para um Estado mínimo. ${ }^{46}$ Dentro dessa perspectiva, quanto à esfera penal, afirmava-se que os serviços sociais prestados à população (entenda-se, aqui, os mais desfavorecidos economicamente) não eram benéficos, mas prejudiciais. Alegava-se para tanto que a assistência social era excessivamente generosa e, consequentemente, retirava a vontade de trabalhar de seus beneficiários, o que promovia uma "dependência prejudicial tanto para os interessados quanto ao país" ${ }^{47}$ Tinha-se, com isso, a manutenção de uma massa de desocupados, os quais, motivados pela desordem do ambiente onde viviam, eram levados à pratica de delitos para ocuparem o seu tempo livre.

Ademais, começa-se a admitir que as finalidades da pena como reabilitação e reinserção social do preso não foram alcançados, isto é, declara-se a falência do modelo correcional de justiça. Logo, a solução apresentada é aquela que visa à diminuição da ajuda social do Governo e à aplicação desses recursos em projetos que visem controlar determinados grupos sociais.

${ }^{45}$ PAVARINI, Massimo. A "grotesca" penalogia contemporânea. Seminário realizado, em 03 de dezembro de 2002. no Doutorado do Centro di Studi sul Rischio - Università di Lecce.

${ }^{46}$ Entenda-se por Estado mínimo, aquele que deve atender as necessidades essenciais da sociedade, permitindo que a maior parte das relações sociais se dê no âmbito intersubjetivo.

${ }^{47}$ WACQUANT, Loïc. Punir os pobres: a nova gestão da miséria nos Estados Unidos. Rio de Janeiro: F. Bastos, 2001. p. 43.
Assim, começa a haver uma busca por um controle mais efetivo de parcelas da população, fazendo com que o discurso sobre o fim da pena mudasse, isto é, deixando de lado a reeducação e buscando a "prevenção”. Verifica-se, portanto, que com a crise das políticas de welfare nos Estados Sociais de Direito, os modelos de correição e a finalidade de prevenção especial também entraram em crise. ${ }^{48}$

Veja-se que o controle das massas consideradas marginalizadas tornou-se política de ordem pública, encontrando no movimento de lei e ordem e de Tolerância Zero um terreno próspero para a difusão de um controle social repressivo. Baseados em um discurso de manutenção da funcionalidade do sistema punitivo, essas abordagens visam, na verdade, segregar, excluir a massa populacional que não atende às necessidades do mercado. Assim, “[...] aqueles que punimos são em larga medida pessoas pobres e extremamente estigmatizadas que precisam mais de assistência do que punição." ${ }^{49}$

Além disso, a mídia atua de maneira decisiva na disseminação desse ideal, pois é ela que promove o sentimento de insegurança na sociedade, divulgando, por meio de programas sensacionalistas, um crescimento desordenado da criminalidade. Dessa forma, sentimentos de medo, desconfiança e de ansiedade começaram a ser disseminados na população. Consequentemente, o reflexo dessa nova política é a construção de mais presídios, a caracterização de mais delitos, o aumento das penas, de uma maneira geral, o recrudescimento do Direito Penal.

[...] a espetacularização da violência na atualidade, recarregada incessantemente pela emissão de cenas em tempo real, suscita dois tipos de sentimentos ambivalente: o primeiro, que se utiliza da banalização e da vulgarização para produzir posturas de apatia, indiferença e embrutecimento; e o segundo, que provoca sensações e reações repletas de medo. Ambos são constitutivos e informadores de uma ordem social essencialmente autoritária, pois, embora com sinais trocados, darão amparo e legitimidade para uma intensificação das medidas punitivas. ${ }^{50}$

${ }^{48}$ PAVARINI, Massimo. A "grotesca" penalogia contemporânea. Seminário realizado, em 03 de dezembro de 2002, no Doutorado do Centro di Studi sul Rischio - Università di Lecce.

${ }^{49}$ BAUMAN, Zygmunt. Globalização: as consequências humanas. Rio de Janeiro, J. Zahar, 1999. p. 132.

${ }^{50}$ FREIRE, Christiane Russomano. A violência do sistema penitenciário brasileiro contemporâneo. O caso RDD (Regime Disciplinar Diferenciado). São Paulo: IBCCRIM, 2005. p. 69. 
Assim, os criminosos não são mais considerados pessoas doentes que devem ser curadas, ou ainda, pessoas ignorantes que devem ser instruídas. Na nova conjectura mundial, os criminosos assumem o papel de verdadeiros monstros, cujas atitudes visam acabar com a paz social que o Estado luta para manter. A todo custo, procura-se responsabilizar individualmente o indivíduo pelos seus atos e, novamente, começa-se a vincular o crime à pessoa do condenado, à sua personalidade, imunizando, assim, o contexto social. Conforme afirma Benoni Belli,

É como se os criminosos fossem indivíduos que 'optaram' pelo caminho do desvio, tornando-se diferentes, possuídos que estariam por uma malignidade intrínseca e imutável. A única forma de evitar que o câncer se espraie por todo o tecido social seria erradicá-lo em sua fase inicial, no nascedouro, por meio da imposição da lei e da ordem, ou seja, pela linguagem da força. Do contrário, o pequeno tumor passará por um processo de metástase, ameaçando a própria continuidade do corpo social. ${ }^{51}$

Assim, para Loïc Wacquant, há uma nova finalidade da pena, isto é, seu “[...] objetivo não é mais prevenir o crime, nem tratar os delinqüentes visando ao seu eventual retorno à sociedade uma vez sua pena cumprida, mas isolar grupos considerados perigosos e neutralizar seus membros mais disruptivos [...]". ${ }^{52}$

Dessa maneira, o preso passa a ser visto como um mal na sociedade e, logo, seu futuro será o encarceramento perpétuo, a sua exclusão. Surge, nesse contexto, a figura do estranho, isto é, daquele sujeito que não pertence a uma determinada realidade, a um determinado círculo social.

Assim, as normas são feitas para atender ao desejo de segurança de uma determinada comunidade e aqueles que não pertencem a esse grupo são os estranhos que devem ser excluídos. Logo, “[...] cresce rapidamente em quase todos os países o número de pessoas na prisão ou que esperam prováveis sentenças de prisão. Em quase toda a parte, a rede de prisões está se ampliando intensamente". 53

Nesse mesmo sentido, o trabalho deixa de ser visto como solução e passa a ser encarado como empecilho. A

\footnotetext{
${ }^{51}$ BELLI, Benoni. Tolerância Zero e democracia no Brasil. São Paulo: Perspectiva, 2004. p.69.

${ }^{52}$ WACQUANT, Loïc. As prisões da miséria. Rio de Janeiro: J. Zahar, 2001. p. 86.

${ }^{53}$ BAUMAN, Zygmunt. Globalização: as consequências humanas. Rio de Janeiro, J. Zahar, 1999. p. 122.
}

busca por investimentos faz com que o discurso sobre o trabalho também mude. A intenção dos Estados é flexibilizar o mercado de trabalho. Zygmunt Bauman esclarece que, por flexibilização, deve-se entender o fim dos hábitos do trabalho regular, permanente, cronometrado e fixo. De outro modo, deve-se acabar com o vínculo empregatício, com a sua manutenção ${ }^{54}$. Contudo, se a ideia é diminuir o uso do trabalho, o que se deve fazer com o contingente de desempregados? Imobilizá-los e isso será feito por meio da prisão. Não há mais interesse em produzir corpos dóceis e úteis, como na era clássica.

Dessa maneira, as normas legais são feitas para atender ao desejo de segurança de uma determinada comunidade, em detrimento da perseguição e segregação de outra. O legislador não cria as normas para seus iguais, mas para os desiguais, para aqueles que não fazem parte do seu círculo social. A consequência desse tratamento desigual se reflete, por parte dos excluídos, em uma busca por rejeitar aqueles que os rejeitam. ${ }^{55}$ Para isso se utilizam da violência, a qual acarreta, em contrapartida, um reforço do estereótipo que se tem dessa classe e na justificação do uso da prisão como solução para o seu afastamento do convívio social. Assim sendo,

\begin{abstract}
A rejeição leva a um esforço de circunscrever as localidades pelo padrão dos campos de concentração. A rejeição dos que rejeitam leva ao esforço de transformar a localidade numa fortaleza. Os dois esforços reforçam os efeitos mútuos e garantem entre si que a fragmentação e o isolamento "na base" continuam sendo os irmãos gêmeos da globalização "no topo".
\end{abstract}

Portanto, hoje há uma nova divisão do mundo, isto é, entre os que possuem mobilidade (liberdade) e os que sofrem com a sua ausência. Graças à globalização, deu-se um novo significado a palavra liberdade. Ela indica promoção social, progresso, sucesso. Em contrapartida, a sua falta reflete a derrota, a vida fracassada e o atraso. ${ }^{57}$ Como se observou até aqui, em cada época da história humana, a prisão se destinou a um objetivo diverso. Todavia, atualmente, nesse novo panorama, a prisão ganhou uma nova função: ‘depósito' dos 'indesejáveis'” ${ }^{58}$

\footnotetext{
${ }^{54}$ BAUMAN, Zygmunt. Globalização: as conseqüências humanas. Rio de Janeiro, J. Zahar, 1999.

${ }_{55}^{55}$ Ibidem, p. 135.

${ }^{56}$ Ibidem, p. 136.

${ }^{57}$ Ibidem, p. 129.

${ }^{58}$ WACQUANT, Loïc. As prisões da miséria. Rio de Janeiro: J. Zahar, 2001. p. 115.
} 


\section{0 trabalho prisional brasileiro}

A concepção de que somente por meio do trabalho o homem poderia se tornar justo e íntegro, cumprindo com seus deveres sociais, foi uma das ideias provenientes da Reforma produzida pelo Protestantismo e pelo Calvinismo ${ }^{59}$. Tal posicionamento fez com que a ideia de ócio fosse rechaçada pela sociedade e, aliado aos ideais capitalistas, ele se transformasse em um aspecto negativo. Esse modo de pensar contribuiu para a construção do raciocínio segundo o qual a pessoa que pratica um delito, dentre outras circunstâncias, faz isso pela falta de dedicação ao labor, isto é, pelo excesso de tempo livre. Como solução, os criminosos eram obrigados a trabalhar, não para aprender um ofício, mas para interiorizar o gosto pelo trabalho e pela disciplina. Além disso, atendiam-se aos anseios de mão de obra que o então capitalismo nascente tanto almejava. Esse modo de pensar e de interpretar a realidade daqueles que praticam delitos criminais perpetuou-se na sociedade ocidental e também foi recepcionada pelo ordenamento jurídico brasileiro, especialmente pelo Sistema Penal. Prova disso se obtém pela simples leitura da Constituição da República Federativa do Brasil de $1988^{60}$, em conjunto com o Código Penal e Processual

\footnotetext{
59 "As religiões protestantes e em particular o calvinismo forneceram sem dúvida, muito mais do que a religião católica, uma visão abrangente do mundo e da vida baseada na ética do trabalho, a religião do capital, que animará por si mesma as primeiras instituições segregadoras. Na passagem da sociedade camponesa medieval para a sociedade burguesa industrial, o trabalhador não está mais sujeito a um vínculo direto e imediato com o senhor, vínculo esse jurídico e militarmente garantido e justificado, ao nível ideológico, por uma visão teocrática abrangente da vida. Ele deve ser conduzido, doravante, por uma força muito mais indireta, a da coação econômica. Porém, só quando o capitalismo alcançar seu completo desenvolvimento, com a garantia da sua hegemonia material e ideológica sobre toda a sociedade, é que a força da necessidade se tornará uma força realmente eficiente de regulação social.". MELOSSI, Dario; PAVARINI, Massimo. Cárcere e fábrica: as origens do sistema penitenciário (séculos XVI XIX). Rio de Janeiro: Revan, 2006. p. 50.

${ }^{60}$ Nesse sentido, faz-se referência ao art. $1^{\circ}$ da Norma Fundamental de 1988 ,quando essa preceitua em seu inciso IV como fundamento da República Federativa do Brasil, os valores sociais do trabalho e da livre iniciativa. Além disso, estabelece o art. 170 do mesmo diploma legal que a ordem econômica, fundada na valorização do trabalho humano e na livre iniciativa, tem por fim assegurar a todos existência digna, conforme os ditames da justiça social.
}

Penal Brasileiro e a Lei de Execução Penal ${ }^{61}$, bem como por especialistas ${ }^{62}$. Ademais, atualmente, o mercado de trabalho é mais seletivo e não admite a entrada de quem não tenha certo grau de profissionalização. Essa é a realidade encontrada nas atividades disponibilizadas aos presos brasileiros que, por um lado, são intituladas como atribuições profissionalizantes, mas, de modo diverso do que pretendem, não auxiliam na especialização de qualquer ofício que hoje é requerido de um trabalhador.

\subsection{Não há trabalho ao qual se reintegrar}

Diversamente ao que prevê a Lei de Execução Penal, os trabalhos oferecidos aos presos não são capazes de produzir o fim que ela almeja, qual seja, a profissionalização do condenado. Isso se deve, em primeiro lugar, ao fato de os trabalhos serem desinteressantes, mecanicistas

${ }^{61}$ No que se refere à finalidade do trabalho prisional, conforme o respectivo artigo 28 da Lei de Execuções Penais (Lei n ${ }^{\circ}$ 7210/1984), ela será educativa e produtiva. Entende-se que a primeira função será realizada na hipótese de ser o condenado pessoa sem qualquer habilitação profissional e a atividade desenvolvida no ambiente prisional irá auxiliá-lo na aprendizagem de uma profissão. Por outro lado, será produtivo, pois retirará o detento do ócio, permitindo que ele adquira meios de compensar os seus gastos na prisão, de auxiliar a sua família e de ressarcir o Estado pela sua manutenção. SILVA, Odir Odilon Pinto da; BOSCHI, José Antônio Paganella. Comentários à lei de execução penal. Rio de Janeiro: Aide, 1986. p. 39. Ademais, afirma Júlio Fabbrini Mirabete que "[...] se já tinha o hábito do trabalho, depois de recolhido ao estabelecimento penal, seu labor irá manter aquele hábito, impedindo que degenere". MIRABETE, Júlio Fabbrini. Execução penal. São Paulo: Atlas, 2004. p. 91.

${ }^{62} \mathrm{O}$ trabalho atende a diversos interesses, conforme salienta Francisco Bueno Arus, do ponto de vista disciplinar, evita o ócio e contribui para que a ordem seja mantida no ambiente carcerário; do ponto de vista sanitário, auxilia o condenado a manter o seu equilíbrio orgânico e psíquico; do ponto de vista educativo, contribui para a formação da personalidade; do ponto de vista econômico, permite que o condenado disponha de algum dinheiro para as suas necessidades e para ajudar a família; e, por fim, do ponto de vista da ressocialização, conhecendo um ofício o condenado tem chances melhores de ter uma vida honrada ao ser libertado. MIRABETE, Júlio Fabbrini. Execução penal. São Paulo: Atlas, 2004. p. 92. No mesmo sentido, afirma Rui Medeiros que "[...] o labor representa a melhor forma terapêutica, o único meio verdadeiramente capaz de eliminar o caráter pernicioso e criminógeno das prisões, tornando a pena corretiva e ressocializante". MEDEIROS, Rui. Prisão aberta. Rio de Janeiro: Forense, 1995. p. 62. 
e, alguns deles, ultrapassados. ${ }^{63} \mathrm{O}$ que se busca, na verdade, é ocupar o tempo livre do condenado e não prepará-lo para o seu retorno à sociedade. Contribui-se, portanto, com a segregação do detento.

Não há o menor interesse em ensinar aos detentos, em geral, ofícios que lhes possam valer no mundo livre, não há qualquer empenho em estimular o gosto pelo trabalho, consideradas as tarefas oferecidas. ${ }^{64}$

Apesar das várias atividades que são oferecidas aos detentos serem intituladas como profissionalizantes, nenhuma delas garante um futuro diferente ao encarcerado. Aprender um ofício durante a sua estada na prisão pode ajudá-lo a não se envolver em brigas, a ser visto com bons olhos pelo corpo administrativo da penitenciária e pode, ainda, diminuir o seu tempo de pena, por meio da remição. Entretanto, ao ser libertado, o egresso não se depara com uma sociedade consciente de que o seu castigo já foi cumprido e que a sua condição de cidadão, igual a todos os demais, foi reestabelecida. Pelo contrário, o estigma deixado pelo ambiente penitenciário é mais forte que a "qualificação profissional" adquirida, o que, consequentemente, acaba prejudicando as suas tentativas de concorrência no mercado de trabalho. Diante de uma oportunidade de emprego na qual há um ex-detento e uma pessoa sem nenhuma condenação penal, a escolha do empregador sempre recai sobre aquele que não possui as marcas "invisíveis" do cárcere. Observa-se, por exemplo, que muitas empresas, durante o processo de seleção,

\footnotetext{
${ }^{63}$ Para mencionar alguns dos trabalhos desenvolvidos pelos presos, têm-se as seguintes atividades sendo realizadas em estabelecimentos prisionais no Brasil: costura industrial (fabricação de lençóis, jalecos, camisolas para os hospitais da rede pública de saúde; uniformes e outras vestimentas para as polícias; além da costura de bandeiras para os diversos órgãos públicos), panificação, marcenaria (concerto de cadeiras e carteiras escolares do ensino público), funilaria, mecânica, serigrafia, fábrica de bolas, serviços administrativos (digitação de documentos de pequena importância, transporte de materiais de um departamento para o outro, bem como a manutenção e conservação dos locais), artesanato. Essas informações foram obtidas nos sítios eletrônicos da Fundação de Amparo ao Trabalhador Preso do Distrito Federal (FUNAP/DF), disponível em: <www.funap.df.gov.br > Acesso em: 15 jan. 2011); da Fundação "Prof. Dr. Manoel Pedro Pimentel" de Amparo ao Preso (FUNAP/SP), disponível em: <www.funap.sp.gov.br>. Acesso em: 15 jan. 2011) e do Ministério da Justiça ,disponível em: www.mj.gov.br. Acesso em: 15 jan. 2011).

${ }^{64}$ ZACKSESKI, Cristina. Relações de trabalho nos presídios. Revista do Ministério Público do Trabalho, Brasília, n. 23, p. 36-37, mar. 2002.
}

pedem aos seus candidatos certidões negativas de antecedentes criminais, como prova de sua idoneidade. ${ }^{65}$

[...] a etiqueta de criminosos atribuída a um indivíduo pela sanção penal diminui as possibilidades de ação do mesmo, ao invés de reinseri-lo na sociedade, onde, provavelmente, nunca esteve inserido, ou, no caso do mercado de trabalho, teve uma inserção limitada, talvez nem isso, como é comum nos dias de hoje. ${ }^{66}$

Veja-se, assim, que o preconceito que um exdetento sofre pela razão de sua passagem por uma Instituição carcerária, aliada à falta de qualificação para a realização de um trabalho diferencial dentro da sociedade, são motivos suficientes para que esse indivíduo seja influenciado a reincidir na prática criminosa e, por sua vez, retornar à penitenciária. Dessa maneira, “[...] a pena privativa de liberdade não ressocializa, ao contrário, estigmatiza o recluso, impedindo sua plena reincorporação ao meio social. A prisão não cumpre uma função ressocializadora". ${ }^{67}$ Percebe-se com isso, que o discurso proferido pelo Direito Penal ao afirmar que buscará reintegrar o indivíduo delituoso à sociedade é equivocada. A passagem de qualquer cidadão por uma instituição carcerária acaba por imprimir nele uma marca, a qual, consequentemente, gera a sua segregação, divergindo, portanto, da sua natureza social.

Por conta disso, pode-se afirmar que o ser humano, por si só, não seria capaz de sobreviver. A sociedade nasce não apenas da união de várias pessoas, mas da interação delas. Logo, é “[...] impossível pretender a reincorporação do indivíduo à sociedade através da pena privativa de liberdade, quando, na realidade, existe uma relação

${ }^{65}$ Segundo Loïc Wacquant, nos EUA, "graças a 'Look up on inmate, qualquer empregador ou proprietário pode, antes da admissão de um assalariado ou do aluguel de um apartamento, assegurar-se sem a menor dificuldade de que o candidato em questão não tenha antecedentes criminais e, portanto, no caso contrário, discriminar na mais plena legalidade segundo o prontuário judicial. Conforme explica, como se fosse uma evidência, a porta-voz da administração penitenciária do estado de Illinois: 'afinal são criminosos, as pessoas têm todo o direito de ter essa informação para que possam se defender deles'. WACQUANT, Loïc. Punir os pobres: a nova gestão da miséria nos Estados Unidos. Rio de Janeiro: F. Bastos, 2001. p. 68.

${ }^{66}$ ZACKSESKI, Cristina. Relações de trabalho nos presídios. Revista do Ministério Público do Trabalho, Brasília, n. 23, p. 45, mar. 2002.

${ }^{67}$ Ibidem, p. 36-37. 
de exclusão entre a prisão e a sociedade". ${ }^{68}$ Ademais, "Los muros de la cárcel representan uma violenta barrera que separa la sociedad de uma parte de sus próprios problemas $y$ conflictos" ${ }^{\prime 69}$ Não se pode buscar a ressocialização de um detento se a sociedade não está disposta a recepcioná-lo. A reintegração social tem início na prisão, mas somente se completa no seu exterior.

\subsection{Incorporação de novos valores}

Conforme apresentado no início desta discussão, Alessandro Baratta afirma que o preso, a partir do momento que ingressa no cárcere, é submetido a um duplo processo de transformação. O primeiro, denominado de processo de "desculturação", faz com que o encarcerado seja afastado dos valores e comportamentos pertencentes à sociedade extramuros. ${ }^{70}$ Em seguida, há a "aculturação" ou "prisionalização", ou seja, assimilam-se os valores e os comportamentos pertencentes à "subcultura carcerária." ${ }^{1}$

\begin{abstract}
A conclusão a que podemos chegar no tocante à disciplina no interior das prisões nos conduz à assertiva de que o indivíduo é submetido a um autêntico processo de aculturação, para que se torne um preso dócil e disposto a cumprir, acriticamente, todas as determinações das autoridades carcerárias, elevadas pelo sistema penitenciário à metafórica condição de patriarcas onipotentes, que elegem o que é bom ou ruim para os apenados, se os mesmos desejarem a ressocialização. ${ }^{72}$
\end{abstract}

Essa ideia, portanto, é totalmente contrária à ressocialização, pois obriga o condenado a se adaptar a um clima hostil que encontra na prisão. Além disso, o que se espera do preso é que, ao ser libertado, retorne melhor do que entrou. Contudo, diante da realidade imposta pelo ambiente carcerário, a função ressocializadora perde o seu sentido, não alcançando, assim, o fim ao qual fora idealizada.

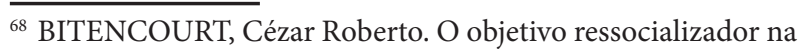
visão da criminologia crítica. Revista dos Tribunais, São Paulo, ano 79, v. 662, p. 250, dez. 1990.

${ }^{69}$ BARATTA, Alessandro. Resocialización o control social: por un concepto crítico de "reintegracion social" del condenado. In: ARAÚJO JÚNIOR, João Marcelo (Org.). Sistema penal para o terceiro milênio: atos do colóquio Marc Ancel. Rio de Janeiro: Revan, 1991. p. 255.

${ }^{70}$ Idem. Criminologia crítica e crítica do direito penal: introdução à sociologia jurídico-penal. Trad. Juarez Cirino dos Santos. Rio de Janeiro: Revan, 2002. p. 184.

${ }^{71}$ BARATTA, op. cit., p. 255.

72 ROIG, Rodrigo Duque Estrada. Direito e prática histórica da execução penal no Brasil. Rio de Janeiro: Revan, 2005. p. 141.
O método utilizado para promover essa incorporação dos modelos de comportamento na prisão é aquele que Michel Foucault já havia apresentado ao tratar do Panóptico de Jeremy Bentham, qual seja, a disciplina. Utilizam-se aqui, duas técnicas que, conforme palavras do autor, deram razão ao sucesso do poder disciplinar: a vigilância hierárquica e a sanção normalizadora. A primeira visa promover um controle constante das atividades dos condenados; e a segunda busca corrigir e reduzir os desvios, aplicando uma política de recompensa e punição. ${ }^{73}$

No mesmo sentido, quanto à primeira técnica, os Projetos de Lei n. ${ }^{\circ} 457,510,1288,1295$ e 1440 , todos de 2007, buscavam estabelecer o monitoramento eletrônico de presos e réus sujeitos à liberdade provisória e suspensão condicional do processo, sendo que apenas o PL n. ${ }^{\circ} 1288$ foi transformado em lei (Lei Ordinária no $12258 / 2010) .^{74}$ Por outro lado, atendendo à segunda técnica, podem ser encontradas algumas diretrizes do Conselho Nacional de Política Criminal e Penitenciária (CNPCP), mais especificamente, na Resolução n. ${ }^{\circ}$ 14, de 11 de novembro de 1994, que apresenta o seguinte:

Art. 28. As medidas coercitivas serão aplicadas, exclusivamente, para o restabelecimento da normalidade e cessarão, de imediato, após atingida a sua finalidade.

\section{[...]}

Art. 55. Em cada estabelecimento prisional será instituído um sistema de recompensas, conforme os diferentes grupos de presos e os diferentes métodos de treinamento, a fim de motivar a boa conduta, desenvolver o sentido de responsabilidade, promover o interesse e a cooperação dos presos. ${ }^{75}$

Portanto, cabe ao preso agir, bem como atuar de acordo com as regras da instituição e com as determinações do corpo funcional. Além disso, o preso é ainda forçado a conviver com diversos tipos de criminosos. Ao contrário do que determina a lei, que os detentos deveriam ser separados conforme o sexo, a idade e o tipo de delito cometido, o que se vê na realidade é o descumprimento dessa disposição legal. Observa-se, portanto, que todo detento, independentemente do crime cometido, é

${ }^{73}$ FOUCAULT, Michel. Vigiar e punir: nascimento da prisão. Petrópolis: Vozes, 1987.

${ }^{74}$ Disponível em: <http://www.camara.gov.br>. Acesso em: 15 fev. 2011.

${ }^{75}$ Disponível em: <http://www.mj.gov.br>. Acesso em: 15 fev. 2011. 
obrigado pelas próprias circunstâncias a conviver com os mais diversos tipos de presos e a sua sobrevivência nesse ambiente depende diretamente da sua adequação com os seus novos "colegas". Dessa forma, percebe-se que o preso é despido de sua realidade extramuros e é impelido a assumir novos valores. Nesse contexto, o trabalho prisional serve apenas como uma "terapia ocupacional".

Um pensamento que vigora na mente do corpo administrativo das instituições penitenciárias é de que o preso é um ser ocioso e que busca o trabalho para, por meio da remição, diminuir o seu tempo de estada no cárcere. Entretanto, os trabalhos oferecidos não têm o objetivo real de prepará-los profissionalmente, mas visam incutir nos detentos o hábito pelo trabalho. Assim, o que se vê é a reprodução de um estilo de vida ligado a um tipo de trabalho característico das parcelas mais desfavorecidas da população. Logo, ao recuperar a liberdade, o egresso não possui qualificação suficiente que lhe permita disputar melhores colocações no mercado de trabalho.

Portanto, diante dessa realidade, podemos afirmar que, “[...] nas atuais circunstâncias, o confinamento é antes uma alternativa ao emprego, uma maneira de utilizar ou neutralizar uma parcela considerável da população que não é necessária à produção e para a qual não há trabalho 'ao qual se reintegrar". ${ }^{76}$ Dessa forma, fica claro que há um total descompasso entre a norma e a sua aplicação ao caso concreto. Conforme já mencionado, o Direito Penal apresenta duas funções: a declarada (que visa, com a pena, retribuir o mal cometido com o crime e buscar a reinserção social do condenado) e a latente (promove-se uma segregação seletiva).

Assim, apesar de o Brasil não ter adotado uma política, declarada, de Estado Penal, suas ações quanto à aplicação da norma penal e tratamento dos condenados já vêm caminhando para essa forma de organização estatal. Ademais, a segregação promovida no Brasil faz parte de sua história e está diretamente relacionada à desigualdade estrutural de sua sociedade, que é caracterizada por relações sociais hierárquicas. ${ }^{77}$ Ressalte-se, ainda, que essa tradição brasileira de segregação já vem sendo abordada pela sua literatura, como se observa a seguir:

\footnotetext{
${ }^{76}$ BAUMAN, Zygmunt. Globalização: as consequências humanas. Rio de Janeiro: J. Zahar, 1999. p.119-120.

${ }^{77}$ BELLI, Benoni. Tolerância Zero e a democracia no Brasil. São Paulo: Perspectiva, 2004.
}

O Brasil parece seguir essa mesma tendência de progressiva redução do Estado às suas funções policiais e carcerárias. $\mathrm{O}$ problema maior, no entanto, é que o Estado de bem-estar nunca se universalizou no Brasil, de modo que seu desmantelamento deve gerar um precariação ainda mais intensa do que aquela observada nos países desenvolvidos. ${ }^{78}$

Portanto, como já alegado por Alessandro Baratta $^{79}$, não há como pretender mudanças significativas no sistema penal, se a metodologia utilizada para sua análise baseia-se em um estudo positivista que parte da própria lei. Em outras palavras, se a avaliação continuar a ser feita de uma perspectiva interna da ciência jurídica, o que alçaremos será apenas uma reelaboração da ideologia da Defesa Social. Não será possível escapar às armadilhas dessa ideologia e, muito menos, romper com ela. Logo, o que se propõe é uma crítica externa levando em consideração tanto as verificações feitas pelas ciências jurídicas, como também as pesquisas já realizadas pelas ciências sociais acerca do assunto. Dessa maneira, a Política Criminal não deve ser limitada pelo Direito Penal, ao contrário, compete à Política Criminal estabelecer os limites de atuação do Direito Penal.

\section{Conclusão}

Ao longo deste artigo, utilizaram-se como base teórica as contribuições da Criminologia Crítica, a qual promoveu um estudo mais aprofundado da forma de atuação do sistema penal e, com isso, revelou a crise de legitimidade pelo qual ele passa. Com base nesses estudos, a Criminologia desenvolveu o seu argumento a partir das características de desigualdade, seletividade, violação dos direitos humanos, arbitrariedade, que identificam este sistema e que colaboram para sua utilização como uma forma de controle social.

Não obstante essas considerações, a dogmática jurídica e o senso comum ainda compartilham as noções sobre crime e pena, presentes naquilo que Alessandro Baratta chama de Ideologia da Defesa Social. Quanto ao objeto de nossa pesquisa, não é diferente. Associado à

\footnotetext{
${ }^{78}$ BELLI, Benoni. Tolerância Zero e a democracia no Brasil. São Paulo: Perspectiva, 2004. p. 85.

${ }^{79}$ BARATTA, Alessandro. Criminologia crítica e crítica do direito penal: introdução à sociologia jurídico-penal. Trad. Juarez Cirino dos Santos. Rio de Janeiro: Revan, 2002.
} 
ideia de ressocialização, o trabalho prisional é, no discurso jurídico, apontado como uma ferramenta importante no processo de reabilitação do condenado, porque afirma que, por meio dele, o condenado poderá aprender os valores sociais, terá a oportunidade de sair do cárcere como uma pessoa melhor e facilitará a sua reinserção no meio social. Em outras palavras, dentro da nossa legislação e da interpretação doutrinária que se faz dessa legislação, o trabalho tem finalidades positivas e está, portanto, relacionado à função ressocializadora da pena. Entretanto, ao longo da história da pena privativa de liberdade e mesmo antes dela, o trabalho teve funções distintas.

O período feudal sempre esteve ligado à ideia de punição. Mesmo antes do surgimento da pena de prisão, que considera a restrição da liberdade como sendo a sanção propriamente dita, o labor já era aplicado como punição aos transgressores da lei. Apesar disso, as transformações econômicas e sociais promovidas pela sociedade fizeram com que determinadas concepções em relação à pena mudassem e, consequentemente, a forma de utilização do trabalho do encarcerado.

Observou-se com o surgimento do capitalismo e das ideias provenientes das reformas religiosas, realizadas pelo Calvinismo e Protestantismo e que ocorreram juntamente com o declínio do Estado Absolutista, que o trabalho prisional passou a ser considerado como um instrumento útil para o tratamento do delinquente. Entretanto, por trás desse sentimento nobre, sempre se esconderam necessidades diversas daquelas proferidas pelo discurso oficial, ou seja, a lei. Em um primeiro momento, o cárcere atendeu à falta de mão de obra que prejudicava as manufaturas, produzindo servidores dóceis e obedientes, introduzindo em cada indivíduo o gosto pelo trabalho. Para tanto, a disciplina foi o método utilizado para a produção desses novos empregados, pois concentrava, em uma única ação, diversas formas de controle.

Já com o gradativo desenvolvimento tecnológico, como visto na seção 1 , o mercado de trabalho passou a exigir pessoas cada vez mais qualificadas tecnicamente para realização dos serviços. Apesar de o trabalho prisional não ter acompanhado essas transformações, devido aos elevados custos que essas mudanças requeriam para habilitar os encarcerados à nova realidade, ele continuou sendo considerado como um instrumento de recuperação do condenado. Porém, mais uma vez, o verdadeiro intuito permaneceu encoberto, ou seja, ao invés de se pro- duzir mão de obra, o labor prisional passou a ser utilizado como uma forma de controle da massa encarcerada, uma vez que ela não tinha trabalho ao qual ser reintegrada.

Abandonou-se, assim, na prática, a ideia de reinserção social do condenado, a qual ainda prevaleceu por algum tempo no plano das ideias. Contudo, em meados da década de 60 e 70 do século XX, alguns países como, por exemplo, os EUA e a Inglaterra, mudaram o seu discurso e passaram a admitir a falência desse instituto e a prática penal tomou um novo rumo, visando à exclusão dos denominados criminosos. Em outras palavras, nenhuma inovação aconteceu, o que essa "nova" política criminal fez foi deixar claro uma prática que há muito tempo se escondia atrás discursos humanitários.

Dessa forma, percebe-se que as intenções pretendidas pelas normas que regulam a aplicação e execução do trabalho prisional divergem da realidade que espera o encarcerado, isto é, conforme já foi dito, o sistema penal apresenta duas funções: a declarada e a latente. Ademais, a sociedade demonstra uma contradição de interesses, pois, por um lado, legitima a utilização da prisão como meio de sanção das práticas delituosas e forma de reabilitação dos considerados delinquentes. Por outro lado, não colabora com o retorno daqueles que já cumpriram os seus castigos, auxiliando a sua segregação e colaborando com a reprodução da desigualdade social. Dessa forma, conforme preceitua Alessandro Baratta, "não se pode segregar pessoas e pretender ao mesmo tempo reintegrá-las". ${ }^{80}$

\section{Referências}

ANDRADE, Vera Regina Pereira de. Do paradigma etiológico ao paradigma da reação social: mudança e permanência de paradigmas criminológicos na ciência e no senso comum. Revista Seqüência, Santa Catarina, n. 30, 1995.

BARATTA, Alessandro. Criminologia crítica e crítica do direito penal: introdução à sociologia jurídico-penal. Rio de Janeiro: Revan, 2002.

\footnotetext{
${ }^{80}$ BARATTA, Alessandro. Resocialización o control social: por un concepto crítico de "reintegracion social" del condenado. In: ARAÚJO JÚNIOR, João Marcelo (Org.). Sistema penal para o terceiro milênio: atos do colóquio Marc Ancel. Rio de Janeiro: Revan, 1991. p. 254.
} 
BARATTA, Alessandro. Resocialización o control social: por un concepto critico de "reintegración social" del condenado. In: ARAÚJO JÚNIOR, João Marcelo (Org.). Sistema penal para o terceiro milênio: atos do colóquio Marc Ancel. Rio de Janeiro: Revan, 1991. p. 251-265.

BAUMAN, Zygmunt. Globalização: as consequências humanas. Rio de Janeiro: J. Zahar, 1999.

BELLI, Benoni. Tolerância Zero e democracia no Brasil. São Paulo: Perspectiva, 2004.

BITENCOURT, Cézar Roberto. O objetivo ressocializador na visão da criminologia crítica. Revista dos Tribunais, São Paulo, ano 79, v. 662, dez. 1990.

FOUCAULT, Michel. A verdade e as formas jurídicas. Rio de Janeiro: Nau, 2001.

FOUCAULT, Michel. Microfísica do poder. Rio de Janeiro: Graal, 1992.

FOUCAULT, Michel. Vigiar e punir: nascimento da prisão. Petrópolis: Vozes, 1991.

FREIRE, Christiane Russomano. A violência do sistema penitenciário brasileiro contemporâneo. $\mathrm{O}$ caso $\mathrm{RDD}$ (Regime Disciplinar Diferenciado). São Paulo: IBCCRIM, 2005.

MEDEIROS, Rui. Prisão aberta. Rio de Janeiro: Forense, 1995.

MELOSSI, Dario; PAVARINI, Massimo. Cárcere e fábrica: as origens do sistema penitenciário (séculos XVI - XIX). Rio de Janeiro: Revan, 2006.
MIRABETE, Júlio Fabbrini. Execução penal. São Paulo: Atlas, 2004.

PAVARINI, Massimo. A "grotesca" penalogia contemporânea. Seminário realizado em 03 de dezembro de 2002, no Doutorado do Centro di Studi sul Rischio Università di Lecce.

PEREIRA, Marcela Plachini. A remição da pena à luz da ressocialização do condenado. Boletim IBCCrim, v. 8, mar./2001.

ROIG, Rodrigo Duque Estrada. Direito e prática histórica da execução penal no Brasil. Rio de Janeiro: Revan, 2005.

RUSCHE, Georg; KIRCHHEIMER, Otto. Punição $e$ estrutura social. 2. ed. Rio de Janeiro: Revan, 2004.

SILVA, Odir Odilon Pinto da; BOSCHI, José Antônio Paganella. Comentários à lei de execução penal. Rio de Janeiro: Aide, 1986.

WACQUANT, Loïc. As prisões da miséria. Rio de Janeiro: J. Zahar, 2001.

WACQUANT, Loïc. Punir os pobres: a nova gestão da miséria nos Estados Unidos. Rio de Janeiro: F. Bastos, 2001.

ZACKSESKI, Cristina. Relações de trabalho nos presídios. Revista do Ministério Público do Trabalho, Brasília, n. 23, mar. 2002.

ZAFFARONI, Eugenio Raul. Em busca das penas perdidas. Rio de Janeiro: Revan, 1991. 


\section{Para publicar na revista Universitas/JUS, acesse $o$ endereço eletrônico www.publicacoesacademicas.uniceub.br.}

Observe as normas de publicação, para facilitar e agilizar o trabalho de edição. 